\title{
Economic consequences of intifada
}

\author{
Paul de Boer \& Marco Missaglia*
}

Econometric Institute Report El 2005-21

\begin{abstract}
In 2003 the World Bank (WB) and the International Monetary Fund (IMF) published estimates of macro-economic indicators for 2002 of the economy of Palestine. WB used a micro-founded recursive dynamic computable general equilibrium (CGE) model, calibrated on the 1998 Social Accounting Matrix (SAM) of Palestine, to which shocks were applied, whereas IMF based its estimates on a macro-founded incomeexpenditure model relying on more recent data. It turned out that there were substantial differences: the estimate by WB of the real Gross National Income (at 1998 prices) was $25 \%$ less than the corresponding figure calculated by IMF. This huge difference is not only relevant for a full understanding of the economic consequences of the intifada, but also for the size of the international community intervention. In this paper we propose our own evaluation with the help of a static CGE model, based on the 1998 SAM and the so-called intifada shock derived from data of WB, that we constructed for the analysis of some forms of emergency assistance in a previous article. It turns out that our estimates, based on an entirely different methodology, are remarkably close to those of IMF.
\end{abstract}

Keywords: Macro-economic indicators, computable general equilibrium model, Palestine

*Dipartemento di Economia Pubblica e Territoriale, Università degli Studi di Pavia, Corso Strada Nuova 65, IT-27100 Pavia, Italy, e-mail: marco.missaglia@unipv.it, tel: + 390382 504357.

May 2005 


\section{Introduction}

The most recent years of the Palestinian history, those of the second intifada, have witnessed a dramatic decline in all Palestinian economic and social indicators. Since September 2000, when the violent confrontations started, conditions for a normal life have nearly disappeared and the economic situation has steadily disintegrated.

Using a poverty line of US\$2.1 per day the World Bank (2003b, pp. i-xiv) estimated the poverty in Palestine in 1998 at $23.2 \%$ of the population, whereas by the end of 2002 the Bank estimated the poverty to have risen to 59 percent. The unemployment rate that amounted to $16.2 \%$ in 1998 rose to $37 \%$ at the end of 2002 . The overall GNI losses have reached US $\$ 5.2$ billion during the first twenty-seven months of intifada, which is more than the GNI in 1998 or in 1999 (US\$ 5.1 billion).

Two main causes of the Palestinian economic crisis are closure, namely the imposition of restrictions on the movement of goods and people across borders and within Palestine, and the destruction of capital. In September 2000 the Bank estimated the number of Palestinians working in Israel and the settlements at 128,000, while the estimate for end 2002 was about 32,000 . The physical damage resulting from the conflict was estimated to be US $\$ 305$ million by the end of 2001 and US $\$ 930$ million by the end of 2002. As a result of damage and of the fall in investment, the real productive capital stock declined by US\$1.7 billion between 1999 and 2002 .

It is clear, in some way even obvious, that an already fragile economy has been hit very hard by the conflict. However, there is no consensus on the extent and the order of magnitude by which the Palestinian economy has suffered during the last years of conflict. Specifically, we will see in the next section that the evaluations coming from the World Bank (World Bank, 2003a, 2003b and 2003c) are substantially different from those of the International Monetary Fund (IMF, 2003). Just to anticipate one figure, according to the WB the GNI in 2002 is $25 \%$ less than the corresponding figure calculated by the IMF. It goes without saying that such a huge difference is relevant not only to a full understanding of the economic consequences of the conflict, but arguably to the size of the international community intervention as well. This is the reason why in this paper we try to propose our own evaluation of the economic consequences of the conflict, with the help of a computable general equilibrium (CGE) model calibrated on the social accounting matrix (SAM) of 1998, a part of which has been presented in appendix 1 of Missaglia and de Boer (2004).

The rest of the paper is organized as follows. Section 2 illustrates the different assessments proposed by international agencies. In section 3 we provide a description of the model used for our own evaluation. Section 4 describes what we called the "intifada shock", i.e. the set of shocks the Palestinian economy has suffered as a consequence of the violent confrontations started in September 2000. Section 5 illustrates the results and compares them with those obtained by the IMF. 


\section{Assessments by international agencies}

Before comparing the significantly different assessments proposed by the World Bank and the IMF (table 2.8), let us have a look at how these different figures are arrived at.

\subsection{Assessment by the World Bank}

The estimates of the World Bank are based on "....a quant itative model which describes the economic relations between households, producers, government and the rest of the world through a set of accounting and behavioral equations...." (cf. World Bank, 2003b, footnote 41). The description of this CGE model can be found in Astrup and Dessus (2001, 2002).

The following tables are derived from the "Summary of Macroeconomic Trends and Projections" that has been published in World Bank (2003c) and contains the same data as published in table 7 of World Bank (2003b) but in more detail.

In table 2.1 we calculate from the annual changes provided by World Bank (2003c) the CPI of 2002 based on $1998=1$ and the compound real growth index of the components of GDP in NIS (1998 prices).

Table 2.1. CPI and compound real growth index of the components of GDP 2002 (NIS, prices 1998)

\begin{tabular}{|l|r|r|r|r|r|r|}
\hline & 1998 & 1999 & 2000 & 2001 & 2002 & $\begin{array}{l}\text { CPI 2002 } \\
(1998=1)\end{array}$ \\
\hline Exchange rate & 3.81 & & & & 4.74 & 1.169 \\
\hline CPI, annual change & .056 & .055 & .027 & .021 & .057 & \multicolumn{1}{c|}{$\begin{array}{l}\text { Compound real } \\
\text { growth index } \\
2002(1998=1)\end{array}$} \\
\hline $\begin{array}{c}\text { Real annual change } \\
\text { (NIS, prices 1998) }\end{array}$ & .731 \\
\hline Private consumption & .090 & .075 & -.056 & -.155 & -.148 & .085 \\
\hline Public consumption & .070 & .203 & .310 & -.021 & -.006 & .612 \\
\hline Total fixed investment & .084 & -.083 & -.283 & -.769 & -.440 & .546 \\
\hline Exports & .066 & .023 & -.088 & -.134 & -.243 & \\
\hline Imports & .074 & .054 & -.162 & -.290 & -.129 & \\
\hline
\end{tabular}

In table 2.2 we give the data on the components of GDP for 1998 in million US\$ (World Bank, 2003c) and calculate the 1998 amounts in NIS based on the exchange rate given in table 2.1. From the data given in table 2.1 we take the compound real growth index $2002(1998=1)$ and the amounts in (real) NIS and in US\$ easily follow. The real GDP of 2002 in NIS is derived by taking the sum of the expenditure components and subtracting the imports. The nominal amounts are taken from World Bank (2003c), whereas the price indices easily follow. The price index of private consumption that we derive is, as it should be, equal to the CPI, derived by us in table 2.1. 
Table 2.2 Estimate of the real components of GDP (in million US\$ or million NIS) and of the price indices

\begin{tabular}{|l|r|r|r|r|r|r|r|}
\hline & \multicolumn{2}{|c|}{1998} & & \multicolumn{4}{|c|}{2002} \\
\hline & $\begin{array}{l}\text { Nominal } \\
\text { US\$ }\end{array}$ & $\begin{array}{l}\text { Nominal } \\
\text { NIS }\end{array}$ & $\begin{array}{l}\text { Compound } \\
\text { real } \\
\text { growth } \\
\text { index }\end{array}$ & $\begin{array}{l}\text { Real } \\
\text { NIS }\end{array}$ & $\begin{array}{l}\text { Real } \\
\text { US\$ }\end{array}$ & $\begin{array}{l}\text { Nominal } \\
\text { US\$ }\end{array}$ & $\begin{array}{l}\text { Price } \\
\text { index } \\
(1998=1)\end{array}$ \\
\hline $\begin{array}{l}\text { Private } \\
\text { consumption }\end{array}$ & 4,014 & 15,293 & .731 & 11,173 & 2,357 & 2,756 & 1.169 \\
\hline $\begin{array}{l}\text { Public } \\
\text { consumption }\end{array}$ & 976 & 3,719 & 1.534 & 5,703 & 1,203 & 1,757 & 1.460 \\
\hline $\begin{array}{l}\text { Total fixed } \\
\text { investment }\end{array}$ & 1,668 & 6,355 & .085 & 541 & 114 & 119 & 1.044 \\
\hline Exports & 624 & 2,377 & .612 & 1,454 & 307 & 345 & 1.125 \\
\hline Imports & 3,052 & 11,628 & .546 & 6,351 & 1,340 & 1,581 & 1.180 \\
\hline GDP & 4,230 & 16,116 & & 12,519 & 2,641 & 3,396 & 1.286 \\
\hline
\end{tabular}

In table 2.3 we give data taken from World Bank (2003c) and calculate the compound real growth indices per capita for $2002(1998=1)$.

Table 2.3 Population and compound real growth index per capita

\begin{tabular}{|l|l|l|l|l|l|l|}
\hline & 1998 & 1999 & 2000 & 2001 & 2002 & \\
\hline $\begin{array}{l}\text { Population, mid- } \\
\text { year }(1,000)\end{array}$ & 2,731 & & & & 3,231 & \\
\hline \multicolumn{8}{|c|}{$\begin{array}{l}\text { Real annual change } \\
\text { (NIS, prices 1998) }\end{array}$} & $\begin{array}{l}\text { Compound real } \\
\text { growth index } \\
\text { per capita }\end{array}$ \\
\hline GNI per capita & .077 & .039 & -.075 & -.232 & -.234 & .565 \\
\hline GDP per capita & .039 & .031 & -.053 & -.195 & -.225 & .609 \\
\hline
\end{tabular}

In table 2.4 we estimate GNI and GDP using the compound real growth index per capita and the data on the population presented in table 2.3. The estimate of real net factor income (NFI) follows from subtracting real GDP from real GNI. The nominal amounts of GNI, GDP and net factor income are taken from World Bank (2003c).

Table 2.4 Estimate of the real components of GNI (in million US\$ or million NIS)

\begin{tabular}{|l|r|r|r|r|r|r|}
\hline & \multicolumn{2}{|c|}{1998} & \multicolumn{4}{|c|}{2002} \\
\hline & $\begin{array}{l}\text { Nominal } \\
\text { US\$ }\end{array}$ & $\begin{array}{l}\text { Nominal per } \\
\text { capita NIS }\end{array}$ & $\begin{array}{l}\text { Compound } \\
\text { real growth } \\
\text { index per } \\
\text { capita }\end{array}$ & $\begin{array}{l}\text { Real per } \\
\text { capita NIS }\end{array}$ & $\begin{array}{l}\text { Real } \\
\text { US\$ }\end{array}$ & $\begin{array}{l}\text { Nominal } \\
\text { US\$ }\end{array}$ \\
\hline GNI & 5,058 & 7,056 & .565 & 3,990 & 2,719 & 3,768 \\
\hline GDP & 4,230 & 5,901 & .609 & 3,595 & 2,450 & 3,396 \\
\hline NFI & 828 & 1,155 & & & 269 & 372 \\
\hline
\end{tabular}

It should be noted that the estimate of GDP reported in table 2.2 (2,641 million US\$) is $10.8 \%$ higher than the one reported in table 2.4 (2,450 million US\$). 


\subsection{Assessment by the International Monetary Fund}

In June 2003, the PCBS published, with the technical assistance of the IMF, a set of annual national accounts statistics for the years 1994 to 2000 (IMF, 2003, p. 22). With the aid of an income-expenditure model the IMF estimated GNI and its components for the years 2001 and 2002. We quote from IMF (2003):

\section{Box 2.5. A simple Income-Expenditure Model to Estimate GDP Developments}

The income-expenditure model starts with the identity GDP equals Exports minus Imports plus Consumption plus Investment. Information on exports in 2001 can be obtained from the preliminary balance of payments (BOP) prepared by the PCBS and the PMA. For 2002, Israeli BOP figures are available, that identify Israeli imports from the "Palestinian Authority", which is broadly equivalent to WBG excluding East Jerusalem in this context. According to trade statistics from the PCBS, about 90 percent of Palestinian exports go to Israel. Imports and private consumption are both assumed to be a linear function of private disposable inc ome (PDI). PDI is equal to GNI less domestic taxes (available from ministry of finance data) plus transfers from abroad (for which some limited data is available from banks). GNI is equal to GDP plus net factor income from abroad, which is mostly labor income from Israel (estimates based on quarterly labor market survey). Public consumption is derived from the fiscal accounts (which are up to date). Investment is based on partial information on public investment from donors project financing and even more partial information on private investment in construction (based on indicators of cement imports and building permits).

The model provides estimates for GDP and certain components in nominal terms. In order to derive GDP in real terms, each demand component is deflated. The most important component of the deflators is the CPI which is complemented by several other price series, such as oil prices and prices in Israel. Historically, the GDP deflator and the $\mathrm{CPI}$ index have in fact been very similar.

In table 2.5 we make use of the fractions of GDP and of the nominal GDP figures reported by IMF (2003, table 2.2) to derive the components for 1998 and 2002.

Table 2.5 GDP and GNI (current prices, million US\$) 1998 and 2002

\begin{tabular}{|l|r|r|r|r|}
\hline & \multicolumn{2}{|c|}{1998} & \multicolumn{2}{c|}{2002} \\
\hline & Fraction & Million US\$ & Fraction & Million US\$ \\
\hline Private consumption & .997 & 4,245 & 1.247 & 3,709 \\
\hline Public consumption & .224 & 954 & .343 & 1,020 \\
Private investment & .264 & 1,124 & .166 & 494 \\
\hline Public investment & .064 & 273 & .035 & 104 \\
\hline Change inventories & .023 & 98 & 0 & 0 \\
\hline Exports & .208 & 886 & .139 & 413 \\
\hline Imports & .780 & 3,321 & .930 & 2,766 \\
\hline GDP & 4,258 & 4,258 & 2,974 & 2,974 \\
\hline Net factor income & .212 & 903 & .145 & 431 \\
\hline GNI & 1.212 & 5,161 & 1.145 & 3,405 \\
\hline Net current transfers & .096 & 409 & .589 & 1,752 \\
\hline Gross disposable income & 1.308 & 5,569 & 1.734 & 5,157 \\
\hline
\end{tabular}


IMF (2003, table 2.1) gives the annual growth of GDP, GNI and CPI. In table 2.6 we use these figures in order to derive the GDP, GNI and, residually, the net factor income (NFI), all in millions US\$, prices 1998 (recall from our table 2.5 that in 1998 the GNI was 5,161 and the GDP 4,258 million US\$). We present our findings in table 2.6.

Table 2.6 Estimate for 2002 of Real GNI, GDP, NFI (million US\$, prices 1998) and CPI (base year 1998)

\begin{tabular}{|c|c|c|c|c|c|c|}
\hline Real annua & $\begin{array}{l}1999 \\
\text { I chan }\end{array}$ & $\begin{array}{l}2000 \\
\text { e (US }\end{array}$ & $\begin{array}{l}2001 \\
\text { prices }\end{array}$ & $\begin{array}{l}2002 \\
1998)\end{array}$ & $\begin{array}{l}\text { Compound } \\
\text { growth index } \\
2002(1998=1)\end{array}$ & $\begin{array}{l}\text { Million US\$ } \\
2002 \text { (prices 1998) }\end{array}$ \\
\hline Real GNI & .084 & -.068 & -.162 & -.164 & .708 & 3,653 \\
\hline Real GDP & .089 & -.054 & -.150 & -.145 & .749 & 3,188 \\
\hline Real NFI & & & & & & 565 \\
\hline $\mathrm{CPI}$ & .055 & .028 & $.012^{\star}$ & .057 & 1.160 & \\
\hline
\end{tabular}

* The World Bank reports a figure of .021 leading to a CPI of 1.169 in 2002.

IMF (2003, table 2.3) reports that the index of real GDP of 2002 with respect to real GDP $1997=100$ is equal to .837 . Since the index of real GDP in 1998 was equal to 118.8 and the nominal GDP in 1998 4,258, we calculate the real GDP in 2002:

$$
\frac{.837 \times 4,258}{1.188}=3,188
$$

which is equal to the real GDP in 2002 reported in our table 2.6, as indeed it should be.

Using the fractions that IMF (2003, table 2.3) reports for 2002, and using the figure of 3,188 million US\$, we arrive at table 2.7 .

\section{Table 2.7. Estimate of the real components of GDP 2002}

\begin{tabular}{|l|r|r|}
\hline \multicolumn{2}{|c|}{2002} \\
\hline & Fraction & $\begin{array}{l}\text { Million US } \$^{*} \\
\text { (prices 1998) }\end{array}$ \\
\hline Private consumption & 1.041 & 3,956 \\
\hline Public consumption & .274 & 1,041 \\
\hline Private investment & .144 & 547 \\
\hline Public investment & .030 & 114 \\
\hline Change inventories & 0 & 0 \\
\hline Exports & .112 & 426 \\
\hline Imports & .762 & 2,986 \\
\hline GDP & .837 & 3,188 \\
\hline
\end{tabular}

${ }^{*}$ We balanced the figures to arrive at GDP $=3,188$

It is puzzling that division of the nominal consumption of 3,709 (cf. our table 2.5) by the real consumption of 3,956 (cf. our table 2.7) does not lead to the CPI of 1.160 (cf. our table 2.6). 


\subsection{Comparison between the World Bank and the IMF}

In table 2.8 we summarize the assessment by the World Bank and the IMF presented in the two previous subsections, as well as their ratio: the assessment of the World Bank as fraction of the one by the IMF.

Table $2.8^{\star}$ Comparison between the assessment by the World Bank and the IMF

\begin{tabular}{|l|r|r|r|r|r|r|r|r|r|}
\hline & \multicolumn{3}{|c|}{1998 (million US\$) } & \multicolumn{3}{c|}{$\begin{array}{c}2002 \text { (current prices, } \\
\text { million US\$) }\end{array}$} & \multicolumn{3}{c|}{$\begin{array}{c}2002 \text { (prices 1998, } \\
\text { million US\$) }\end{array}$} \\
\hline & \multicolumn{1}{|c|}{ WB } & \multicolumn{1}{|c|}{ IMF } & Ratio & \multicolumn{1}{l}{ WB } & IMF & Ratio & WB & IMF & Ratio \\
\hline $\begin{array}{l}\text { Private } \\
\text { consumption }\end{array}$ & 4,014 & 4,245 & .946 & 2,756 & 3,709 & .743 & 2,357 & 3,956 & .596 \\
\hline $\begin{array}{l}\text { Public } \\
\text { consumption }\end{array}$ & 976 & 954 & 1.023 & 1,757 & 1,020 & 1.723 & 1,203 & 1,041 & 1.156 \\
\hline $\begin{array}{l}\text { Total fixed } \\
\text { investment }\end{array}$ & 1,668 & 1,494 & 1.116 & 119 & 598 & .199 & 114 & 661 & .172 \\
\hline Exports & 624 & 886 & .704 & 345 & 413 & .835 & 307 & 426 & .721 \\
\hline Imports & 3,052 & 3,321 & .919 & 1,581 & 2,766 & .572 & 1,340 & 2,896 & .463 \\
\hline GDP & 4,230 & 4,258 & .993 & 3,396 & 2,974 & 1.142 & 2,450 & 3,188 & .769 \\
\hline NFI & 828 & 903 & .917 & 372 & 431 & .863 & 269 & 465 & .578 \\
\hline GNI & 5,058 & 5,161 & .980 & 3,768 & 3,405 & 1.107 & 2,719 & 3,653 & .744 \\
\hline
\end{tabular}

${ }^{*}$ The ratio is the figure of the World Bank divided by the one of the IMF.

The reader may easily notice that the differences between the two evaluations (2002, prices 1998) are relevant and worth stressing. In a sense, one should not be too much surprised: the WB predictions are based on a micro-founded, CGE model, whereas the IMF's are based on a macro, income-expenditure model; the WB based its study on a SAM of 1998, whereas the IMF study relies on some more recent data (see Box 2.5). It would not make any sense to assert that one model is better than the other, since they are usually employed for different purposes. What we want to stress here is the fact that the IMF macro figures are based on more recently available data and thus are likely to describe more appropriately the cost of the conflict. Is it possible to get closer to those (IMF) figures using some analytical tool which is closer to the richer, micro-founded kind of model used by the World Bank? This is the question we try to answer in the rest of this paper.

\section{Description of the model}

\subsection{Introduction}

In the model we have five economic agents: eight producers, one household, a bank that allocates savings over investments, the Palestinian Authority (PA) and the rest of the world (RoW). In their appendix 2 Missaglia and de Boer (2004) present the glossary of symbols and in their appendix 3 the equations of the model.

\subsection{The producers}

Intermediate inputs are combined into the intermediates by means of a Leontief technology, whereas capital and labor are combined into value added by means of a CES technology. Both aggregates are, using the Leontief assumption, combined into 
the supply of the domestically produced commodity. This commodity is transformed via a CET function into an export commodity and into a domestic commodity supplied to the domestic market. This commodity is combined with imports to produce the composite commodity. To that end we adopt the Armington assumption by using a CES functional form. This commodity is either used in the production process (intermediate demand) or for final purposes: consumption, consumption of the PA and investment.

\subsection{The household}

The household owns the capital, receives transfers from the PA and from the rest of the world, and it disposes of a time endowment. The household is assumed to maximize its utility in two stages: in the first one it allocates its time endowment over labor supply and leisure. We allow for unemployment so that the labor demand is smaller than the labor supply. We assume that the unemployed do not receive unemployment benefits.

In the model we use the unemployment theory delineated in the migration literature by Harris and Todaro (1970) to describe the wage gap between rural and urban jobs. Compared to the modified version proposed by Ruppert Bulmer (2001), we stay closer to the original Harris-Todaro model. The core of the theory is described by the following arbitrage condition (acting as a wage curve):

$$
\mathrm{PL}=\left(\frac{\mathrm{LF}}{\mathrm{LF}+\mathrm{UNEMP}}\right) \cdot \mathrm{b} \cdot \mathrm{PLF}
$$

The wage rate paid by Palestinian firms to Palestinian workers, PL, must be equal, in equilibrium, to the expected wage rate of the Palestinian workers employed in Israel or in the settlements. The latter is equal to the wage rate prevailing in Israel and the settlements, PLF, multiplied by the probability of getting a job in Israel or in the settlements and $a$ factor $b$. The probability of getting a job in Israel or in the settlements is simply given by the ratio of the Palestinian workers actually employed in Israel or in the settlements (LF) to the workers who look for a job there: those who manage (LF) and those who do not (UNEMP). The factor $b$ is interpreted to be the inverse of the probability of getting a job in Palestine. Then, the arbitrage condition states nothing but the equality between two expected wages:

\section{$\mathrm{P}$ (Job in Palestine).PL = $\mathrm{P}$ (Job in Israel or in the settlements).PLF}

All sources of income (capital, transfers and wages earned in Israel, the settlements and Palestine) together yield the household income.

The household pays income taxes and saves a fixed fraction out of its income after taxes. Subtracting taxes and savings from income yields the budget that it devotes to the purchase of commodities. In the second stage the household maximizes a utility function, with the consumption of these commodities as arguments, subject to its budget constraint. For both stages we use a Linear Expenditure System (LES).

\subsection{The Palestinian Authority (PA)}

The PA derives its revenues from two sources: taxes (on imports, capital, labor, consumption commodities and on household's income) and foreign aid. These revenues are spent on transfers, savings and on other expenditures. With respect to the latter we assume that the PA maximizes a Cobb-Douglas utility function with its purchases of the 
two commodities "Private Services" and "Public Services" as arguments subject to the expenditure constraint.

\subsection{The bank}

The household savings, the PA savings and the foreign savings are allocated over the investment demand for the commodities. To that end the bank is assumed to maximize a Cobb-Douglas utility function subject to the constraint that savings are equal to total investments.

\subsection{The rest of the world}

For the Palestinian economy, the RoW basically coincides with Israel and its settlements, at least as far as foreign trade is considered. In 1998, 76 percent of imports and 96 percent of exports came from and were directed toward Israel and its settlements (Astrup and Dessus, 2001). Obviously, the picture is different if one looks at foreign aid disbursements. For instance, out of a total of US\$1.1 billion by the end of 2002, US\$ 840 million came from Arab League countries and US\$230 million from the EU (World Bank, 2003a).

Palestine earns revenues from the RoW via exports and other sources: foreign aid accruing to the PA, remittances from the workers employed in Israel or in the settlements, foreign transfers directly accruing to the households and foreign savings, i.e. the deficit in the current account balance. These revenues are spent on imports of goods.

Imports and exports are treated in a rather standard way, through, respectively, an Armington-CES and a CET assumption.

\section{The 1998 Social Accounting Matrix and the counterfactual SAM}

\subsection{The 1998 SAM}

The CGE model used in this paper is calibrated around the SAM constructed by the World Bank for 1998. Compared to this original version, we aggregate the several sectors and sub-sectors included in it to eight main sectors: Food, Other Agriculture, Manufacturing, Construction, Transport, Trade, Private Services and Public Services, each of them producing one good. The food sector is an aggregation of the food producing agricultural activities and of those activities that, although belonging to the Manufacturing sector in the SAM, produce food items as well (for instance the "food and beverages" activity). For more details we refer to section 2.1 of Missaglia and de Boer (2004).

\subsection{The counterfactual SAM}

We built a "counterfactual" SAM by giving a big "intifada shock" to the 1998 benchmark:

\section{A reduction in the capital stock}

According to World Bank (2003a), physical damages resulting from the conflict (private and public buildings, infrastructure, productive trees and soils, etc.) amounted to $14 \%$ of $1998 \mathrm{GNI}$ by the end of August 2002, a huge reduction in the productive capital stock. 
But what we are mainly interested in is the reduction in capital income rather than in capital stock. Missaglia and de Boer (2004) infer that capital income decreased by at least 30\%.

2. A dramatic fall in the level of labor income earned in Israel or in the settlements

According to World Bank (2003a), from September 2000 to the end of 2002, the number of permits was reduced from 128,000 to 32,000 . It would make sense to assume a $75 \%$ reduction in this source of income, but, taking into consideration the rather large number of Palestinians who manage to cross into Israel or its settlements illegally, we have given this variable a $50 \%$ shock.

\section{An increase in donors' disbursements}

According to World Bank staff calculations (2003a), total disbursements increased from around US\$ 400 million to around US\$1.1 billion.

4. A reduction in the household's propensity to save by $50 \%$

5. A reduction in PA saving by $50 \%$

It must be noted that one of the main reasons of this reduction is the withholding of Israel's transfers to the PA concerning the tax revenue collected by the former on behalf of the latter.

6. An increase in the transfers paid by the PA to the households and in the labor subsidies handed out to the "Public Services" sector

We assumed that $90 \%$ of the increase in foreign aid was used by the PA to fund social transfers to the households, whereas the remaining percentage was devoted to the payment of labor subsidies which is a convenient way of modeling the intervention of the PA aimed at absorbing, however partially, the labor market shock suffered by the Palestinian economy (see Missaglia and de Boer,2004).

7. An increase in the labor force

According to the PCBS data (www.pcbs.org), the labor force growth was around $8 \%$.

8. An increase in the parameter $b$ that describes the inverse of the probability of getting a job in Palestine

Its calibrated 1998 value turned out to be 1.178 (equivalent to a probability of getting a job in Palestine of $85 \%$ ); we multiplied it by 2.5 (equivalent to a $34 \%$ probability of getting a job in Palestine). 


\section{Results and comparison}

In the following table we summarize our results (DBM) and compare them to those of the IMF.

Table 2.9* Comparison between DBM and the IMF

\begin{tabular}{|l|r|r|r|r|r|r|}
\hline & \multicolumn{3}{|c|}{1998 (million US\$) } & \multicolumn{3}{c|}{2002 (prices 1998, million US\$) } \\
\hline & DBM & \multicolumn{1}{|c|}{ IMF } & Ratio & DBM & \multicolumn{1}{c|}{ IMF } & \multicolumn{1}{c|}{ Ratio } \\
\hline Private consumption & 3,977 & 4,245 & .937 & 3,658 & 3,956 & .925 \\
\hline Public consumption & 976 & 954 & 1.023 & 1,130 & 1,041 & 1.085 \\
\hline Total fixed investment & 1,675 & 1,494 & 1.121 & 997 & 661 & 1.508 \\
\hline Exports & 729 & 886 & .823 & 467 & 426 & 1.096 \\
\hline Imports & 3,053 & 3,321 & .919 & 2,831 & 2,896 & .978 \\
\hline GDP & 4,304 & 4,258 & 1.011 & 3,421 & 3,188 & 1.073 \\
\hline NFI & 779 & 903 & .863 & 390 & 465 & .839 \\
\hline GNI & 5,083 & 5,161 & .985 & 3,811 & 3,653 & 1.043 \\
\hline
\end{tabular}

${ }^{*}$ The ratio is the figure of MDB divided by the one of the IMF.

As the reader may easily see from the column "2002....", the main difference between our results (DBM) and the IMF results concerns total fixed investment, which is larger in $\mathrm{DBM}$, and private consumption, which is lower in DBM. One reasonable explanation for this difference can be found in the role played in our model by the "Construction" sector. Indeed, "in the Palestinian economy more than half of total investment is concentrated into unproductive investment, such as residential building..." (Astrup and Dessus, 2002, p.18). This kind of investment (or at least a part of it: its annual equivalent) should be assimilated, from the point of view of its economic impact, to consumption, something that does not add anything to the productive capacity of the economy. However, in the SAM we used to calibrate the model almost the whole output of the "Construction" sector is classified as "investment". This may explain the origin of the observed difference. The other items of DBM and IMF are extremely close to each other, which means that the "intifada shock" we imposed on the model is reasonable and, arguably, the modeling itself makes sense.

Consequently, it turns out that it is possible to get closer to the IMF figures using our model which is closer to the richer, micro-founded model used by the World Bank.

The conviction that our model can be profitably used to simulate, for instance, the impact of different foreign assistance policies and eventually other policy shocks (see Missaglia and de Boer, 2004) has been reinforced by the outcomes of this study. 


\section{References:}

Astrup, C. \& Dessus, S. (2001) Trade options for the Palestinian economy: some orders of magnitude, MENA Working Papers Series \# 21, The World Bank.

Astrup, C. \& Dessus, S. (2002) Exporting labor or goods: long term implications for the Palestinian economy, MENA Working Papers Series \# 29, The World Bank.

Harris, J. \& Todaro, M. (1970) Migration, unemployment and development: a two-sector analysis, The American Economic Review, 60, pp.126-142.

IMF (2003) West Bank and Gaza: economic performance and reform under conflict conditions, September 2003.

Missaglia, M. \& de Boer, P.M.C. (2004) Food-for-work versus cash-for-work: emergency assistance in Palestine, Economic Systems Research, 16, pp. 367- 390.

Ruppert Bulmer, E. (2001) The impact of future labor policy options on the Palestinian labor Market, MENA Working Paper Series \# 24, The World Bank.

World Bank (2003a) Two years of intifada, closure and Palestinian economic crisis: an Assessment, March 2003.

World Bank (2003b) Twenty-seven months-intifada, closure and Palestinian economic crisis: an Assessment, May 2003.

World Bank (2003c) West Bank and Gaza Update, A quarterly Publication of the West Bank and Gaza Office, April- June 2003. 